\section{Traust og oppskriftsmessig om kols}

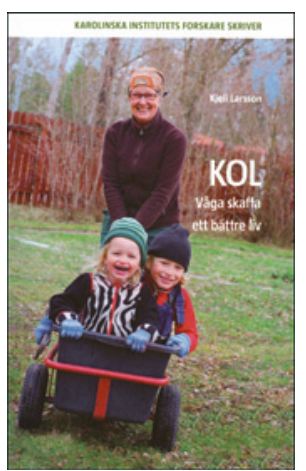

\author{
Kjell Larsson \\ KOL \\ Våga skaffa ett bättre liv. 142 s, tab, ill. \\ Stockholm: Karolinska Institutet University \\ Press, 2012. Pris SEK 212 \\ ISBN 978-91-85565-47-4
}

Målgruppen for denne håndboken om kols er røykere - med eller uten kols. Med et slikt utgangspunkt skulle forfatteren kunne toppe bestselgerlistene. Men vil målgruppen lese boken? Jeg tror de fleste røykere betakker seg. Og jeg forstår dem godt. Riktignok heter den Våga skaffa ett bättre liv, men en mer dekkende tittel ville vært «sånn kan det gå hvis du fortsetter å røyke». Med andre ord, ingen lystelig skjebne.

Karolinska Insitutet har utgitt flere liknende håndbøker i en serie kalt «forskare skriver». Bøkene tar for seg vanlige sykdommer og er ment som informasjon til pasienter og pårørende. Tidligere utgitte bøker omhandler blant annet diabetes, Alzheimers sykdom og multippel sklerose.

Forfatter av boken om kols (eller kol som sykdommen forkortes på svensk) heter Kjell Larsson, professor og spesialist i lungesykdommer. Han har lagt den opp dels som en minilærebok, dels som en lang (og deprimerende) sykehistorie. I tradisjonell lærebokstil er det kapitler om anatomi og fysiologi, risikofaktorer for kols, symptomer og utredning, behandling og kompliserende sykdommer. Røyking har rimeligvis fătt en sentral plass.

Alternerende med disse kapitlene er fortellingen om ekteparet Erik og Annika flettet inn. Den starter med at Erik blir tungpusten og må stoppe i bakken opp fra «sommarstugan». Erik har røykt i 20 år og klarer ikke å slutte, mens Annika for lengst har stumpet røyken. Erik fortsetter å røyke, og det går som vi må frykte. Ved første møte er Erik en yrkesaktiv, hostende og kortpustet 56-åring. Så går det nedover. Plagene baller på seg, han blir stadig verre, oppskriftsmessig og forutsigbart. I siste kapittel venter Erik på «färdtjänstbilen» som skal frakte ham hjem fra «sjukgymnasten». Han er 70 år og «bunden til sin syrgas», har gjennomgått hjerteinfarkt og utallige luftveisinfeksjoner, han har utviklet osteoporose og «åldrats betydligt under de senaste åren». Riktignok klarte han til slutt å stumpe røyken, og Annika er fortsatt trofast til stede. Men ellers er det stusselig. Og Erik har bare seg selv å takke. Han sa nei til «røkslutargruppen». Og legen vrir kniven rundt med «jag kan inte se att du har gått $i$ vår KOL-skola». Moralen er: Hva var det vi sa. Så ille kan det gå.

Dette er en traust og systematisk fremstilling av kols. Den er lettlest og godt illustrert - korrekt, på alle vis. Og den er usigelig kjedelig. Men er det forfatterens skyld? Jeg tror ikke det. Kanskje enhver håndbok om kols er dømt til å bli kjedelig. La meg forklare før jeg får illsinte lungeleger på nakken. Kols er en kjedelig sykdom fordi den i utgangspunktet er enkel og banal. Det skyldes røyking og fjerner vi røyken, fjerner vi kols. Ingen gåte (som Alzheimers sykdom). Ingen kode å knekke (som multippel sklerose). Ingen tabloide førstesideoppslag om forskere som står foran det store gjennombruddet og snart kan avsløre årsaken til kols. Jeg skal være den første til å anbefale kolspasienter å lese, på det området gir sykdommen ingen begrensning. Men det er mange bøker jeg vil anbefale fremfor denne.

\section{May Brit Lund}

Lungeavdelingen

Oslo universitetssykehus, Rikshospitalet

\section{Inspirerende om tvangslidelser - teori og praksis blir god klinikk}

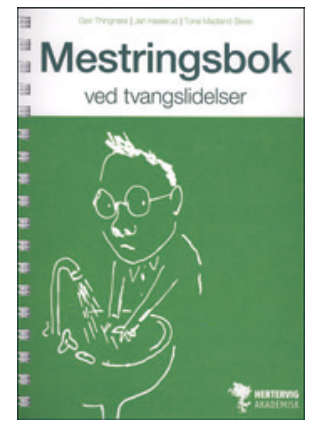

\author{
Geir Thingnes, Jan Haslerud,
}

Tone Madland Skeie

Mestringsbok ved tvangslidelser

3. utg. 241 s, ill. Stavanger: Hertervig

akademisk, 2012. Pris NOK 275

ISBN 978-82-8217-203-5

Målgruppen er pasienter, behandlere, pårørende og andre som er berørt av, eller interesserte i, tvangslidelser og hvordan vi kan mestre dem. Første utgave kom i 2003, og dette er tredje utgave som er revidert og utarbeidet på bakgrunn av erfaringer fra gruppepoliklinikken ved Psykiatrisk divisjon ved Stavanger universitetssjukehus.

Dette er ikke først og fremst er en selvhjelpsbok, men et samarbeidsprosjekt hvor pasienten og behandleren samarbeider for å skape mestring.

Forfatterne baserer seg på kontrollerte studier av eksponering med responsprevensjon, kognitive tilnærminger og bruk av medikamenter, og hvordan flere tilnærminger kan forsterke og berike hverandre. De peker på at det er viktig å velge den behandlingsformen som gir best symptomlette på kortest mulig tid, og at bedringen opprettholdes.

Boken er inndelt i fire deler og 48 oversiktlige kapitler, hvor bidragsyterne beskriver kontakt- og ressursfasen, kartleggingsfasen, problemløsningsfasen og avslutningsfasen. I tillegg er det en oversikt over mestringskurs ved tvangslidelser (OCD), OCD-team, kontaktinformasjon til OCD-foreningen Ananke, supplerende faglitteratur og tidsskrifter. Hvert kapittel er også utstyrt med gode litteraturlister. Siden dette er ringperm, er det lett å kopiere arbeidsoppgaver og andre sider i løpet av terapiprosessen.

Vi følger Herbert, en oppdiktet pasient, som gjennom boken lærer seg å mestre sine problemer. Hvert kapittel avsluttes med pasientens arbeidsoppgaver og sentrale litteraturhenvisninger, slik at man beholder søkelyset på samarbeid og mestring hele tiden.

Denne mestringsboken for tvangslidelser er gjennomarbeidet og samtidig lettfattelig. Forfatterne har klart det mesterstykke å forenkle uten å banalisere eller bli overfladiske, noe som fordrer solid klinisk erfaring ved siden av god oversikt over litteraturen. Språket er lettfattelig og godt.

Forfatterne peker på at det å sette søkelyset på for mange problemområder kan forlenge behandlingstiden for tvangslidelser. Det er en av grunnene til at dette ikke må oppfattes som en selvhjelpsbok, men et felles arbeidsredskap for behandler og pasient.

En av de store utfordringene vi står overfor i dag, er at vi med konvensjonelle behandlingsmetoder, selv om de er virksomme, aldri vil kunne nå alle dem som trenger hjelp. Behandlingen må effektiviseres og presiseres uten at de virksomme elementene går tapt.

Dette er et godt skritt på veien.

\section{Fred Holsten}

Seksjon for psykiatri

Universitetet i Bergen 